\title{
The Multi-Rater System: An Alternative parametric approach in determining Stakeholder Influence and Analysis
}

\author{
Dr. Dan Kipley \\ School of Business and Management, Azusa Pacific University \\ PO Box 7000, Azusa, CA. 91702 \\ Tel: 1-626-815-6000Ｅ-mail: dkipley@apu.edu \\ Dr. Alfred O. Lewis \\ Department of Business, Montreat College \\ P.O. Box 1267, Montreat, NC. 28757 \\ Tel: 1-828-669-8011Ｅ-mail: alewis@montreat.edu
}

\begin{abstract}
Much of the literature dedicated to stakeholder identification has been focused from a 'top-down' view as a determinant of analysis. In this paper, we develop, test, and provide evidence on a new conceptual stakeholder model extending the existing analysis methodology by utilizing a new framework that not only examines the robust interactions occurring between stakeholder groups, but confirms congruence on variables identifying power, influence, and resistance with the Conventional methodology. Using data sampled from a faith-based university of nine hundred and twenty-six stakeholders representing seven stakeholders groups, the study confirms congruency exists between the Conventional and Multi-Rater systems. Additional results indicate a robust identification of stakeholder groups when using the Multi-Rater system which the Conventional system failed to reveal.
\end{abstract}

Keywords: Multi-Rater Methodology, Stakeholder Influence, Stakeholder Analysis 


\section{Background}

To compete successfully in today's global market environment, extant literature and research have acknowledged that is it becoming increasingly important and even indispensable for organizations to complete an analysis and identification of stakeholder groups (Bryson, Bromiley, \& Jung, 1990; Bryson \& Bromiley, 1993; Burby, 2003; Margerum, 2002). This is evidenced by management's publication of the firm's annual reports which communicates the firm's overall position to its stakeholders. Add emphasis in the report on certain stakeholder groups is evidence of the leverage that stakeholders have over a firm (Frooman, 1999). Without identification and analysis of stakeholders and subsequent determination of the group's influence, the organization won't know who exactly the stakeholder groups are and what criteria are they using to judge the organization's performance (Boschken, 1994; Rainey, 1997; Rainey \& Steinbauer, 1999; Rainey, 2003). The organization's overall performance is ultimately determined by the nexus of these combined internal and external forces and an awareness of implementing the proper strategic management tools.

\subsection{Stakeholder Defined}

Throughout this research various definitions of the term "stakeholder" were encountered, including the following variants used to define the public and nonprofit sector: "All parties who will be affected by or will affect the organization's strategy" (Nutt \& Backoff, 1992); "Any person, group, or organization that can place a claim on the organization's attention, resources, or output, or is affected by that output" (Bryson, 1995); "People or small groups with the power to respond to, negotiate with, and change the strategic future of the organization" (Eden \& Ackermann, 1998); "Those individuals or groups who depend on the organization to fulfill their own goals and on who, in turn, the organization depends" (Johnson \& Scholes, 2002). Although these definitions describe the overall role of the stakeholder, they are too general for use in this research. The decision on what definition to use is significant as it affects who and what counts (Mitchell, Agle, \& Wood, 1997). Thus, for specificity, this research will define stakeholders using an educational focus described by Freeman (1984) as follows: "Those interest groups which can affect or be affected by the achievement of the university's objectives regarding educational matters in structure or manner, regardless of level."

The research definition of "stakeholder" is derived in part from a compilation of defining variables from several authors (Freeman, 1984; Bryson, 1995; Nutt \& Backoff, 1992). It includes among defined interest groups the Council for Christian Colleges and Universities (CCCU), and the University administration, senates, board members, staff, faculty, students, alumni, parents, and donors.

This research recognizes that indirect external stakeholders, such as federal and city governments as well as local businesses, may be affected by decisions made by the University as a result of the ripple effect and that many interactions and dynamics exist among the various stakeholder groups. However, this study will be limited to those stakeholders who benefit as a direct effect of the University's decision making. For this reason, this study will be focused on those stakeholder groups described as administration, staff, faculty, students, alumni, parents, and donors. 


\subsubsection{Importance of Stakeholder Identification}

Stakeholder influence has been proven to be a critical factor in the ability of an organization to achieve its strategic goal and objectives (Bryson et al., 1990; Bryson \& Bromiley, 1993; Burby, 2003; Margerum, 2002; Nutt, 2002; Tuchman, 1984). This study will examine the influence that internal stakeholders have in achieving their aspirations as compared to the successful formulation and implementation of the strategic policies, procedures, and programs of a private university.

The effects of stakeholder identification and of stakeholder influence on the performance of an organization are critical factors. Management must know how to accurately identify stakeholders, assess their current and future impact on organization performance, and "manage" the various stakeholder group interests, in order to best develop their organization's strategic future (Powell, 1990; Heclo, 1978; Aldrich \& Whetten, 1981; Feldman \& Khademian, 2002; Radin, 2002).

As previously mentioned, the organization's performance and strategic success is determined by its ability to recognize those internal and external forces which influence its environment and to implement a strategy that matches the level of environmental turbulence (Ansoff \& McDonnell, 1990). Freeman (1984), builds on the work of Ansoff (1965), Evan (1966), and Ackoff (1974), and has argued that a corporate strategy can be understood as a way of building bridges with its stakeholders. Freeman argues that the corporate strategy can only be successful if it satisfies the needs of its multiple stakeholder groups (Freeman, 1984). Stakeholder theory provides a comprehensive insight into the role that stakeholders play in the strategic decisions and strategic future of the organization (Eden \& Ackermann, 2002; Frooman, 1999; Freeman, 1984). Stakeholder theory views stakeholders in three ways;

1. Those that have an interest in the success, rather than failure of the organization;

2. Those whose stake in the organization is focused on disrupting the strategy if they feel that it threatens their own interests; and

3. Stakeholders whose interests are neither pro nor con with respect to the organization's success, but merely regulatory, such as governmental agencies.

\section{Conventional Methodology}

Historically, the common managerial approach to stakeholder understanding was to simply forecast their actions and to adopt a defensive position, rather than trying to strategically manage and understand their actions (Bryson, 1995; Freeman, 1984). As such, there was little need to determine levels of aggregation or disaggregation of stakeholders as it was of little use to management to understand the motivation behind the behaviors of the stakeholder groups. The subtle difference is that one views the stakeholder as adversarial whereas the other views the stakeholder as a contributor to the organization's success. Preston and Sapienza (1990) state the first listing of stakeholders appeared in the 1930s, confirming Dodd (1932) who cites General Electric as the first company to identify employees, customers, and the general public as key constituent groups. Freeman (1984) asserts that the term "stakeholder" is actually derived from the Stanford Research Institute term for "stockholder," defining it as those groups without whose support the organization would cease to exist. 
Freeman's appraisal of the stakeholder is confirmed and validated by Nutt and Backoff's definition (1992) of all parties who will be affected by or will affect the organization's strategy, and by Johnson and Scholes (2002) whose definition of the organizational stakeholder adds depth to the dimension of stakeholder by identifying the self-interests of those "individuals or groups who depend on the organization to fulfill their own goals and on who, in turn, the organization depends."

Thus, researchers commonly agree with the position of the stakeholder theory that stakeholders are driven by a "goal seeking" agenda, each with varying loci of power, and that management's awareness of the primacy of stakeholders' agendas is essential to the organization's success. It is imperative to understand that "stakeholder goal seeking is only central to the loci of power determining their strategies for achieving their goal" (Eden \& Ackermann, 2002). Therefore, determining the locus of power and interest within any stakeholder group is vital, but this information alone is insufficient. Management must also comprehend the potential influence of each group in order to "strategically manage" the stakeholders.

Current stakeholder assessment methodology has primarily focused on identification and analysis from either a senior leadership view or an independent consultant's perception (Bryson, 2004; Peters, 1996; Light, 1997; Osborne \& Plastrik, 1997; Barzelay, 2001; Kettl, 2002).

Consequently, it could be argued that this type of stakeholder analysis reflects a single optic perspective, that of senior management or an outside analyst, and that possibly this single optic presents a biased view of the stakeholder for purposes of identification and analysis.

The methodology utilized in this research is a modified version of the Multi-Rater performance feedback tool. The purpose this method of data collection is to focus on the primacy of each stakeholder group's perception of the other interested stakeholder groups with respect to their levels of power and influence, and their effect on the university's policies, programs, or procedures.

\subsection{For-Profit/Not-for-Profit Organizations}

Traditionally, organizations were seen distinctly either as "for-profit" (FP) or "not-for-profit" (NFP); the FP organizations were viewed as internally efficient, externally entrepreneurial and aggressive, and having a single-mindedness of maximizing corporate profit. Conversely NFP organizations, universities in particular, were seen as the main source of knowledge production, dissemination, and preservation, serving the public's greater good (Newman, 1996; Flexner, 1968; Tierney, 1994) and viewed as internally bureaucratic, economically inefficient, and lacking inspiration; their sole purpose was to provide some nebulous form of "public service" with no intent of maximizing profit and little drive to increase effectiveness.

Paradoxically, the division today between the NFP and FP organizations has become increasingly difficult to distinguish. As competition within the education industry becomes more intense, universities are required to respond to the economic needs of the organization and to be more accountable, requiring universities to engage in marketplace competition, a FP necessity (Levin, 2001). Demands are made on administrators to be more efficient and aggressive, like their counterparts in the private sector, forcing conditions of institutional 
isomorphism (DiMaggio \& Powell, 1983).

As a result of this environmental shift, non-profit organizations have been motivated to become increasingly entrepreneurial and creative, traits that until recently were only attributed to FP organizations. Veblen (1954) describes this movement of universities towards business entrepreneurship as precautionary, possibly having a discouraging and stifling effect on the free exchange of ideas and knowledge, thus intensifying the discourse between the primacy of academia and need for financial legitimacy. This "utilitarian position" now places the university with a policy that is not only concerned with the consequences of accountability, but also the concerns of serving the greatest good for the greatest number of people.

Resultant of these increased environmental pressures combined with the advancement of technology, universities are responding by implementing online courses and virtual classrooms, thus adding to the versatility of their curriculum. Additionally, universities are becoming more diversified and "intentionally internationalized" as well as offering unique tuition schedules, enabling tuition affordability to a wider range of students, all in an effort to open the market to a broader spectrum of students and to differentiate itself from its competition. This response to the increased environmental pressures is a driver in the firm's shift of position in its organizational life cycle. Jawahar and McLaughlin (2001) assert that as the firm transitions from one stage of the organizational life cycle to the next, certain stakeholders will become more or less important than others. The strategy that the organization employs to address each stakeholder depends on the relative importance that each stakeholder has to the success of the firm.

As a result of the shift in the organization's life cycle, and the introduction of new programs, policies, or strategies, a stakeholder analysis must be performed to assess the support, resistance, or coalitions created, in order to develop a strategic plan for managing the groups. As universities compete for market position the need will become increasingly critical for capital, as such, the university will rely more heavily on donor funds to achieve its strategic goals giving donors increasing power and influence over university decisions. An example of donor influence was illustrated at Oral Roberts University in 2007 when the university received a $\$ 62$ million donation from a businessman, but the donor placed stipulations on how the money could be spent, only $\$ 8$ million would be for immediate use and the balance withheld until the businessman could review the university's finances. Research by Kells (1992), has demonstrated that universities facing funding constraints have responded to their new funding sources power and influence. With such knowledge, donor stakeholder interests as well as all stakeholder groups must be assessed when formulating any new strategy (Rainey, 1997).

\subsubsection{Purpose of this Study}

The purpose of this study is therefore multifaceted:

1. To substantiate the Multi-Rater model's ability to identify and accurately rate the various stakeholder groups and their perceived influence on the University's policies, procedures, and programs.

2. To validate the use of the Multi-Rater feedback methodological model as an effective tool 
for determining stakeholder influence on policies, procedures, and programs.

3. To provide administration with an additional analysis tool in which to identify stakeholder groups and their influence on new policies, programs, and procedures, thus enabling a planned, proactive measure to prevent potential misconceptions and opposition to the implementation of the policies, procedures, or programs.

4. To develop an action plan to increase support for a planned reform policy.

5. To add to the repository of knowledge available to the public by providing an additional lens in which to identify and analyze the various stakeholder groups' power and influence in the decision making process.

6. To help guide administration in developing a participatory, consensus building process through sharing the information obtained with the stakeholders and encouraging discussions on how to address the concerns of the opposition.

7. To identify those "fringe strategic stakeholders," people or groups who may or may not have something directly or indirectly at stake in a specific project, but who are in a position to influence the outcome.

8. To assess each stakeholder group as in previous analyses: Utilizing the Multi-Rater methodology will enable administration to compare multi-rated assessments to assessments made by administration thus enabling senior management with a holistic view of stakeholder identification and influence.

\section{Multi-Rater Methodology}

Multi-Rater methodology, also known as multi-source feedback, is a general management performance measurement tool and refers to a process in which individuals receive feedback from multiple sources and perspectives. It is often used in employee development and enrichment as well as performance evaluation (Lepsinger \& Lucia, 1997). Additional concepts relating to Multi-Rater feedback found in literature include 360-degree feedback, upward feedback, reverse feedback, and full-circle feedback (Bracken, Timmreck, \& Church, 2001).

Multi-source feedback is not a unique method. The practice, philosophy, and performance measurements of feedback principles are grounded in the basic need for management to develop a method to evaluate and measure its subordinates, teams, or peers (Nadler, 1977; Latham \& Wexley, 1994). Campbell et al. (1993) suggest that the value of the multi-source assessment is that it provides the rater with information that is difficult to obtain or, in some cases, unavailable, such as peers evaluating facilitation of team performance, or subordinates evaluating supervision.

Multi-source assessments also include a self-review by the employee, which makes the approach "360 degrees." Once the results are compiled, they are shared with the employee in an effort to gain improved understanding of job skills, behavior, and strengths and weaknesses, which can provide insight into professional core competence development. Wolfe (1998) describes personal competencies as those distinguishing characteristics of successful performance and lists any combination of the following as a competence: knowledge, skill, trait, values/beliefs, motives, and physical abilities. 


\section{Al Macrothink}

The definition of Multi-rater assessment reflects conceptual methodologies that denote the focal point feedback, thus making the assessment 360 degrees. This principle was the foundation for the methodology used in gathering the data for this study, but with modifications based on the "multi-source feedback" of London and Smither (1995). The authors describe the "multi-source feedback" method as a circle of bystanders who, from their point of view, indicate the degree in which specific behaviors apply to the focal person. The focal person also responds to the feedback on him or herself in a self assessment, and the results of the self-rating of the focal person are compared with the average of what the circle of bystanders thinks of him or her.

It must be noted however that in order to conduct a successful multi-source feedback, it must be free of an organizational "vacuum." Management must acknowledge that people worked and evaluated each other in the context of a socialized organizational communication system consisting of information gathering, sharing, feedback, and recognition. Lepsinger and Lucia (1997) support the need for clear open communication when they state that a "core requirement is clear and frequent communication."

In summary, multi-source rating can be valuable to administration in understanding stakeholder group positions, as well as assisting in determining common grounds for understanding when dealing with sensitive stakeholder issues. For specificity, the following sections and references in this research will use the term "Multi-Rater feedback" as the method of stakeholder analysis. The fundamental rationale in utilizing the Multi-Rater method of stakeholder analysis is that the data gathered from the various stakeholder groups will provide unique and meaningful information on the perceived power and influence of each separate stakeholder group.

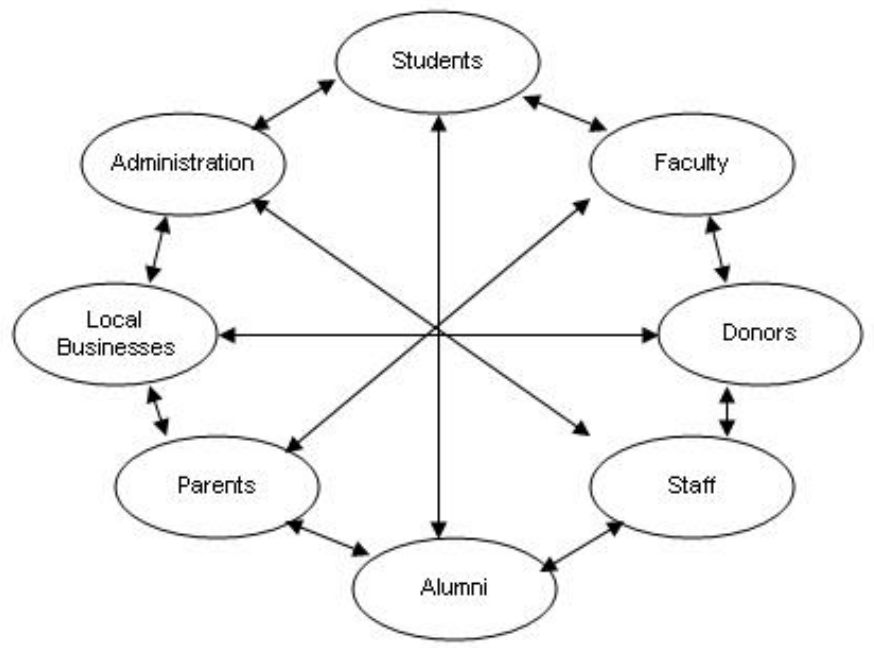

Multi-Rater Feedback Model

Figure 1. Multi-Rater Feedback Model

Utilizing this data and applying correlational statistics will provide the necessary components to determine the level of cognitive congruency between senior management's perception of 
stakeholder power and influence, and that of the stakeholder groups themselves. The results will contribute to intelligibility in the University decision making processes and will illuminate the role of the stakeholder in defining university policies, programs and procedures.

To determine how university stakeholders perceive their influence and the influence of other stakeholder groups in the decision making process, they will be asked a series of questions using an online survey tool to focus on the following general areas of study:

1. How does each stakeholder group perceive its level of power and influence on University policies, programs, and procedures?

2. How does each stakeholder group perceive its position of power and influence in relation to other stakeholder groups?

3. Which stakeholder groups' power is perceived to be growing?

4. Which stakeholder groups' power is perceived to be diminishing?

5. Which stakeholder groups are most likely to present resistance to a stated policy, program, or procedure?

\subsection{About the University under study}

The University studied in this research (unnamed but designated in this text as the "University," with an uppercase U) is an evangelical Christian university whose heritage extends over 100 years and is a product of three merged Christian institutions. The University is located in the Southwestern United States, offering 50 undergraduate degrees, 23 Master's level degrees, 7 Doctoral degrees, and over 40 national and international study opportunities.

\section{Research Questions and Hypotheses}

To understand the relationship, actual or potential, between stakeholders' influence and the decision making process of administration using Conventional methodology juxtapose Multi-rater methodology, the following underpinning research questions (RQ) were posed:

- RQ1 -What is the difference between administration's perception of stakeholder power and influence on programs, policies, and procedures, and stakeholders' perception of their power and influence on programs, policies, and procedures?

- RQ2- What is the difference between administration's perception of stakeholder resistance on programs, policies, and procedures, and stakeholders' perception of their resistance on programs, policies, and procedures?

- RQ3- What is the relationship between results of "Conventional" stakeholder analysis methodology and the results of "Multi-rater" stakeholder analysis methodology?

The following hypotheses were used to complete the study and illuminate the relationship between the 'Conventional methodology' and the 'Multi-rater methodology. 
- H1: There is a significant mean difference in the perceived level of power and influence on programs, policies, and procedures from administration and stakeholder groups.

- H01: There is no significant mean difference in the perceived level of power and influence on programs, policies, and procedures from administration and stakeholder groups.

- H2: There is a significant mean difference in the perceived level of resistance on programs, policies, and procedures from administration and stakeholder groups.

- H02: There is no significant mean difference in the perceived level of resistance on programs, policies, and procedures from administration and stakeholder groups.

- H3: There is a reliable relationship between results obtained from the "Conventional" methodology of stakeholder identification and the results obtained from the "Multi-rater" methodology of stakeholder identification and analysis.

- H03: There is no reliable relationship between results obtained from the "Conventional" methodology of stakeholder identification and the results obtained from the "Multi-rater" methodology of stakeholder identification and analysis.

\subsection{Research Variables}

The following section provides the conceptual and operational definitions for the variables used in this research, as well as any relevant literature pertaining to the variables.

\section{Independent Variables}

Faculty, students, alumni, donors, staff, parents, and administration are all independent variables in the research hypotheses.

\section{Construct Variables}

University policies, procedures, and programs that will best illuminate and identify the research subject stakeholder groups are; intentional internationalization, online learning, diversity, campus expansion, additional academic programs, and retention;

\section{Intervening Variables}

Length of employment is an intervening variable and may influence the survey results in that new employees' responses may demonstrate a limited socio-political awareness of stakeholder groups' power and influence or historical awareness of background relevant to university policies, procedures, and programs.

\section{Dependent Variables}

Power, influence, and Level of Resistance are the dependent variables in all hypotheses.

\subsection{Definition of Terms}

Influence is a social and personal relationship of power and exchange based on the exploitation of some kind of special relationship. Influence in normally exercised in private areas, backstage, or behind the scenes. It is known about, hinted at, but generally not 
observed (Ball, 1987). For specificity, the survey questionnaire will define influence as: to affect the nature of, development, or condition of; to modify; an effect or change produced by influence.

Power is defined as the ability or capacity to exercise control or authority, and force exerted or capable of being exerted.

Resistance is defined as 'the action of opposing something that you disapprove of or disagree with'.

Intentional internationalization as described by DeWit (2002: 119) as "International education as a more developed activity involving a 'program or organization"' Internationalization is an extension of international education and involves "a more strategic process approach" (DeWit, 2002). Altbach (2002a: 29) offers a definition of internationalization as "those specific policies and initiatives of individual academic institutions, systems, or countries that deal with global trends."

Online learning: The terms "online learning, "online delivery" and "virtual education" tend to be used interchangeably to refer to study of credit and non-credit courses from world-wide remote sites that are neither bound by time or physical location. The terms "flexible delivery" and "distance education" often appear to be used in contexts which assume online education. These are defined as the interaction between all participants to enhance educational transactions through the use of communication technologies. Sims (1999) describes these reciprocal events as "those functions that allow learner control, facilitating program adaptations based on learner input, allowing various forms of participation and communication, and acting as an aid to meaningful learning." Such transactions include student-teacher interaction; student-content interaction; teacher-teacher interaction; teacher-content interaction; and content-content interaction.

Retention is a measure of the number of students who persist in their studies from one year to the next; making due allowance for students who leave studies because of finishing a program of study and graduating.

Stakeholder Group is "Any group or individual who can affect or be affected by the achievement of the organization's objectives" (Freeman, 1984: 46). The term is neutral and descriptive, and is valuable in emphasizing the breadth of responsibility of educational institutions, but its use should not obscure the fact that different groups of stakeholders (e.g., students, employers) have quite different interests or needs. This research examines the influence of seven stakeholder groups: administration, staff, faculty, students, alumni, parents, and donors.

\subsection{Research Approach and Objectives}

This study was undertaken using population data derived from a single University for the research purpose of determining the viability and effectiveness of a new methodological approach, the multi-source feedback approach, to determine the effect of stakeholder influence on the university's policies, programs, and procedures. The research approach used 
for this study was both descriptive and correlational.

Correlation measures the relationship between two or more quantifiable variables with the correlation coefficient represented as a number between -1 and +1 that measures a linear relationship of strength and direction. The magnitude of the number represents the strength of the correlation. Additionally, this study will utilize the $t$ test to measure the differences between groups as well as ANOVA, MANOVA, and correlation (Pearson's $r$ ) to detect relationships between the variables.

\subsection{Research Population}

The data collection method used was purposive and random sampling. That means that the sample was drawn at random from a population in which each member had an equal or other specified chance of inclusion. The research population for this study included the following groups:

Table 1.

$\begin{array}{lcccc}\text { Stakeholder Group } & \text { Research Population } & \text { Sample Frame } & \text { \#of Responding } & \% \\ \text { Students } & 4722 & 1250 & 354 & .28 \\ \text { Faculty } & 352 & 352 & 106 & .30 \\ \text { Staff } & 602 & 400 & 235 & .59 \\ \text { Parents of undergraduates } & 4722 & 1000 & 117 & .117 \\ \text { Administration } & 30 & 30 & 28 & .93 \\ \text { Alumni } & * * * & 300 & 111 & .37\end{array}$

Due to the sensitive nature of the stakeholder group "donors," the survey tool was not administered to this group. However, the "donor" stakeholder group remained in the research as a variable for the multi-source ratings from the remaining identified stakeholder groups.

\subsection{Instrument and Procedure}

Survey Monkey online survey site was used to distribute the survey instrument for the data collection. All respondents of the survey were directed to a cover letter prior to site entry describing the purpose of the study and explaining the participant's bill of rights.

\subsection{Assumptions}

The following assumptions were made in developing, conducting, and analyzing this study's research model and data.

1. The research model and statistics were appropriate for this study. 
2. The survey respondents understood and were able to answer the questions in the survey tool.

3. The respondents were familiar with, or could gain access to, information with which to answer the survey questions.

4. The respondents provided accurate and honest answers to the best of their ability.

5. The respondents were able to accurately and objectively evaluate relationships with other identified stakeholder groups.

6. All respondents were a representative of only one of the identified stakeholder groups.

\section{Research Findings}

The primary focus of this research was to determine the feasibility and effectiveness of the Multi-rater methodology of stakeholder identification and analysis as compared to the existing stakeholder analysis methodology.

\subsection{Findings for Hypothesis 1}

Hypothesis 1 predicted that there is significant mean difference in the perceived level of power and influence on the programs, policies, and procedures from 'Conventional' to the 'Multi-rater methodology. It was expected that power and influence would be used by those groups whose self-interest is best served, as well as those groups who will most likely benefit. Additionally, power and influence would be used by a group whose self-interests will most likely be threatened.

The results of the Cronbach's alpha test of reliability are illustrated in Table 1 and indicate survey question reliability, followed by the display of the ANOVA test of means, as indicated in Table 2, the results of which reveal the means for all questions between all groups were significant at $p<0.05$.

The null of hypothesis 1 stated that there was no significant mean difference in the perceived level of power and influence on the programs, policies, and procedures from 'Conventional' to that of the 'Multi-rater' methodology. The statistical results indicate that there is a significant mean difference, $p<0.05$, in the level of power and influence that 'Conventional' and 'Multi-rater' on the University's programs, policies, and procedures. Therefore, the null hypothesis 5 was rejected.

Table 2. Cronbach's Reliability Statistics Hypothesis 1

\begin{tabular}{|l|l|l|}
\hline Cronbach's Alpha & Cronbach's Alpha on Standardized Items & N of Items \\
\hline .872 & .881 & 10 \\
\hline
\end{tabular}


Table 3. ANOVA Test Results of the Difference of Perceived Level of Power and Influence from 'Conventional' to 'Multi-rater' Methodology

\begin{tabular}{|c|c|c|c|c|c|c|}
\hline & & Sum of Squares & df & Mean Square & $\mathrm{F}$ & Sig. \\
\hline \multirow[t]{3}{*}{ Q21 } & Between Groups & 5.262 & 5 & 1.052 & 1.397 & .223 \\
\hline & Within Groups & 653.386 & 867 & .754 & & \\
\hline & Total & 658.648 & 872 & & & \\
\hline \multirow[t]{3}{*}{ Q22 } & Between Groups & 8.064 & 5 & 1.613 & 2.635 & .022 \\
\hline & Within Groups & 526.275 & 860 & .612 & & \\
\hline & Total & 534.338 & 865 & & & \\
\hline \multirow[t]{3}{*}{ Q24 } & Between Groups & 19.514 & 5 & 3.903 & 6.061 & .000 \\
\hline & Within Groups & 548.667 & 852 & .644 & & \\
\hline & Total & 568.182 & 857 & & & \\
\hline \multirow[t]{3}{*}{ Q25 } & Between Groups & 81.463 & 5 & 16.293 & 15.111 & .000 \\
\hline & Within Groups & 929.389 & 862 & 1.078 & & \\
\hline & Total & 1010.853 & 867 & & & \\
\hline \multirow[t]{3}{*}{$25 \mathrm{a}$} & Between Groups & 64.312 & 5 & 12.862 & 11.874 & .000 \\
\hline & Within Groups & 933.783 & 862 & 1.083 & & \\
\hline & Total & 998.096 & 867 & & & \\
\hline \multirow[t]{3}{*}{$25 b$} & Between Groups & 83.355 & 5 & 16.671 & 14.214 & .000 \\
\hline & Within Groups & 1011.000 & 862 & 1.173 & & \\
\hline & Total & 1094.355 & 867 & & & \\
\hline \multirow[t]{3}{*}{$25 \mathrm{c}$} & Between Groups & 93.812 & 5 & 18.762 & 14.640 & .000 \\
\hline & Within Groups & 1104.707 & 862 & 1.282 & & \\
\hline & Total & 1198.520 & 867 & & & \\
\hline \multirow[t]{3}{*}{$25 \mathrm{~d}$} & Between Groups & 140.621 & 5 & 28.124 & 27.067 & .000 \\
\hline & Within Groups & 895.669 & 862 & 1.039 & & \\
\hline & Total & 1036.289 & 867 & & & \\
\hline \multirow[t]{3}{*}{$25 \mathrm{e}$} & Between Groups & 18.650 & 5 & 3.730 & 3.475 & .004 \\
\hline & Within Groups & 925.346 & 862 & 1.073 & & \\
\hline & Total & 943.995 & 867 & & & \\
\hline \multirow[t]{3}{*}{ MEAN } & Between Groups & 33.147 & 5 & 6.629 & 15.300 & .000 \\
\hline & Within Groups & 377.842 & 872 & .433 & & \\
\hline & Total & 410.989 & 877 & & & \\
\hline
\end{tabular}


In hypothesis 1 , analysis revealed that there is a significant mean difference in the perceived level of power and influence from 'Conventional' to that of the 'Multi-rater' methodology. As can be seen from Figure 2, 'Conventional' methodology views the most powerful groups significantly different from the 'Multi-rater' methodological view.

\begin{tabular}{|c|c|c|}
\hline Program & Conventional & Multi-Rater \\
\hline International Campus Expansion & $\begin{array}{l}\text { 1- Admin } \\
\text { 2- Donors }\end{array}$ & $\begin{array}{l}\text { 1- Admin } \\
\text { 2- Students }\end{array}$ \\
\hline Online Learning & $\begin{array}{l}\text { 1- Admin } \\
\text { 2- Faculty }\end{array}$ & $\begin{array}{l}1 \text { - Faculty } \\
2 \text { - Admin }\end{array}$ \\
\hline Campus Diversity & $\begin{array}{l}\text { 1- Admin } \\
2 \text { - Faculty }\end{array}$ & $\begin{array}{l}\text { 1-Students } \\
2 \text { - Admin }\end{array}$ \\
\hline Main Campus Expansion & $\begin{array}{l}1-\text { Admin } \\
2-\text { Donors }\end{array}$ & $\begin{array}{l}1 \text { - Admin } \\
2-\text { Donors }\end{array}$ \\
\hline Additional Academic Programs & $\begin{array}{l}\text { 1- Faculty } \\
2 \text { - Admin }\end{array}$ & $\begin{array}{l}1 \text { - Faculty } \\
2 \text { - Admin }\end{array}$ \\
\hline Student Retention & $\begin{array}{l}1 \text { - Faculty } \\
2 \text { - Admin }\end{array}$ & $\begin{array}{l}1 \text { - Admin } \\
2 \text { - Faculty }\end{array}$ \\
\hline
\end{tabular}

Figure 2. Finding for Hypothesis 1 - Perceived Power

The results revealed that, excluding administration, the 'Multi-rater' methodology view the students stakeholder group as having substantial power (rated number one or two) when dealing with the programs of international campus expansion and campus Diversity. Additional findings reveal that the 'Conventional methodology' perceive donors as the second most powerful group in international campus expansion. Both the 'Conventional' and 'Multi-rater' methodology confirm the alignment of most powerful groups in the program of main Campus expansion and additional academic programs.

\begin{tabular}{|c|c|c|}
\hline Program & Conventional & Multi-rater \\
\hline International Campus Expansion & $\begin{array}{l}\text { 1- Admin } \\
\text { 2- Faculty }\end{array}$ & $\begin{array}{l}\text { 1- Admin } \\
\text { 2- Faculty/Donors }\end{array}$ \\
\hline Online learning & $\begin{array}{l}\text { 1- Admin } \\
\text { 2- Faculty }\end{array}$ & $\begin{array}{l}1 \text { - Faculty } \\
2 \text { - Admin }\end{array}$ \\
\hline Campus Diversity & $\begin{array}{l}\text { 1- Admin } \\
2-\text { Faculty/Students }\end{array}$ & $\begin{array}{l}\text { 1-Admin } \\
\text { 2- Students }\end{array}$ \\
\hline Main Campus Expansion & $\begin{array}{l}1-\text { Admin } \\
2-\text { Donors }\end{array}$ & $\begin{array}{l}1-\text { Admin } \\
2-\text { Donors }\end{array}$ \\
\hline Additional Academic Programs & $\begin{array}{l}1 \text { - Faculty } \\
2 \text { - Admin }\end{array}$ & $\begin{array}{l}1-\text { Admin } \\
2-\text { Faculty }\end{array}$ \\
\hline Student Retention & $\begin{array}{l}1-\text { Faculty } \\
2-\text { Staff }\end{array}$ & $\begin{array}{l}1-\text { Admin } \\
2-\text { Faculty/Students }\end{array}$ \\
\hline
\end{tabular}

Figure 3. Findings for Hypothesis 1 - Perceived Influence

Figure 3. illustrates the perception of stakeholder influence on the listed University programs. 


\section{1) Macrothink}

These results support the perceptions of influence of both the student and staff groups. Hypothesis 1 reveals that the student stakeholder group is perceived by the other stakeholders to have significant power and influence on three of the six listed programs and the staff group is perceived by administration as second most influential for student retention.

As these results reveal, there is a significant mean difference in the perceived level of power and influence on programs, policies, and procedures from the 'Conventional' methodology to the 'Multi-rater' methodology, therefore, the null hypothesis was rejected.

\subsection{Findings for Hypothesis 2}

The findings for hypothesis 2 reveal that there is a significant difference in the perceived level of resistance to the listed programs, policies, and procedures from the 'Conventional' to that of 'Multi-rater' methodology. As can be seen in Figure 3, additional analysis of the resistance reveals a dichotomic view from 'Conventional' and 'Multi-rater'.

The results of the Cronbach's alpha test of reliability are illustrated in Table 3 and indicate survey question reliability. Theses results are followed by the display of the ANOVA test of means results, shown in Table 4, which reveal that the means for all questions between all groups were significant at $p<0.05$.

\begin{tabular}{|c|c|c|}
\hline Program & Conventional & Multi-rater \\
\hline International Campus Expansion & $\begin{array}{l}\text { 1- Faculty } \\
\text { 2- Staff }\end{array}$ & $\begin{array}{l}\text { 1- Parents } \\
\text { 2- Donors }\end{array}$ \\
\hline Online learning & $\begin{array}{l}\text { 1- Faculty } \\
\text { 2- Staff }\end{array}$ & $\begin{array}{l}1 \text { - Faculty } \\
2 \text { - Admin }\end{array}$ \\
\hline Campus Diversity & $\begin{array}{l}1 \text { - Faculty } \\
2 \text { - Students }\end{array}$ & $\begin{array}{l}\text { 1- Students } \\
\text { 2- Parents }\end{array}$ \\
\hline Main Campus Expansion & $\begin{array}{l}1 \text { - Faculty } \\
2 \text { - Donors }\end{array}$ & $\begin{array}{l}1 \text { - Admin } \\
2 \text { - Donors }\end{array}$ \\
\hline Additional Academic Programs & $\begin{array}{l}1 \text { - Admin } \\
2 \text { - Faculty }\end{array}$ & $\begin{array}{l}1-\text { Admin } \\
2 \text { - Faculty }\end{array}$ \\
\hline Student Retention & $\begin{array}{l}1 \text { - Students } \\
2 \text { - Faculty }\end{array}$ & $\begin{array}{l}1 \text { - Students } \\
2 \text { - Admin }\end{array}$ \\
\hline
\end{tabular}

Figure 4. Findings Hypothesis 2 - Resistance

Table 4. Cronbach's Reliability Statistics Hypothesis 2

\begin{tabular}{|l|l|l|}
\hline Cronbach's Alpha & Cronbach's Alpha on Standardized Items & N of Items \\
\hline .853 & .854 & 6 \\
\hline
\end{tabular}


Table 5. ANOVA Test Results of the Difference of Perceived Level of Resistance on Programs, Policies, and Procedures from 'Conventional' and 'Multi-rater'

\begin{tabular}{|l|l|l|l|l|l|l|}
\hline & & Sum of Squares & df & Mean Square & F & Sig. \\
\hline Q27 & Between Groups & 5.427 & 5 & 1.085 & 1.465 & .199 \\
\hline & Within Groups & 594.117 & 802 & .741 & & \\
\hline & Total & 599.545 & 807 & & & \\
\hline V3 & Between Groups & 39.084 & 5 & 7.817 & 9.777 & .000 \\
\hline & Within Groups & 641.182 & 802 & .799 & & \\
\hline & Total & 680.266 & 807 & & & \\
\hline V4 & Between Groups & 22.962 & 5 & 4.592 & 5.222 & .000 \\
\hline & Within Groups & 705.314 & 802 & .879 & & \\
\hline & Total & 728.276 & 807 & & & \\
\hline V5 & Between Groups & 29.177 & 5 & 5.835 & 6.816 & .000 \\
\hline & Within Groups & 686.594 & 802 & .856 & & \\
\hline & Total & 715.771 & 807 & & & \\
\hline V6 & Between Groups & 13.115 & 5 & 2.623 & 3.710 & .003 \\
\hline & Within Groups & 567.003 & 802 & .707 & & \\
\hline & Total & 580.118 & 807 & & & \\
\hline V7 & Between Groups & 60.271 & 5 & 12.054 & 17.697 & .000 \\
\hline & Within Groups & 546.282 & 802 & .681 & & \\
\hline & Total & 606.553 & 807 & & & \\
\hline
\end{tabular}

Most noteworthy of these findings is the perception of 'Conventional' of faculty as being most resistant in four of the six programs and second most resistant in the remaining two.

The perceptions revealed by 'Multi-rater' on the program of "online learning" aligns with the perception of the 'Conventional' methodology which would be the pragmatic conclusion given that faculty would be most resistant to a program that would interfere with their locus of power.

Additional findings reveal the staff group is considered second most resistant by 'Conventional' in international campus expansion and online learning.

The null hypothesis states that there is no significant mean difference in the perceived level of resistance on the programs, policies, and procedures from 'Conventional' to 'Multi-rater' methodology. The results from the ANOVA test were significant, thus the null hypothesis was rejected.

\subsection{Findings for Hypothesis 3}

The results from hypothesis 3 indicate that the relationship between the "Conventional" stakeholder analysis methodology and the "Multi-rater" stakeholder analysis methodology was inconclusive. More specifically, of the three variables measured, power, influence, and resistance, power was the single variable that measured $p<.05$, indicating that the null hypothesis failed to reject. As can be seen from Figure 4, the mean difference between 
"conventional" and "multi-rater" methodology with variables influence and resistance was relatively proximate at .1374 and .362 respectively.

The statistical analyses utilized in hypothesis 3 were both the $t$ test and a MANOVA. Results of both tests are indicated in Figures 5 and 6.

\begin{tabular}{|l|l|l|l|l|}
\hline & Group & Mean & Std. Deviation & $\mathrm{N}$ \\
\hline MEAN POWER & 1 & 3.1232 & 1.04955 & 23 \\
\hline & 2 & 2.4643 & .82070 & 784 \\
\hline & Total & 2.4831 & .83452 & 807 \\
\hline MEAN INFLUENCE & 1 & 3.4348 & .68486 & 23 \\
\hline & 2 & 3.2974 & .69523 & 784 \\
\hline & Total & 3.3013 & .69490 & 807 \\
\hline MEAN RESISTANCE & 1 & 2.0217 & .65193 & 23 \\
\hline & 2 & 1.8550 & .68293 & 784 \\
\hline & Total & 1.8598 & .68224 & 807 \\
\hline
\end{tabular}

Figure 5. Findings for Hypothesis 8 - $t$ Test Descriptive Statistics

\begin{tabular}{|l|l|r|r|r|r|}
\hline $\begin{array}{l}\text { Dependent } \\
\text { Variable }\end{array}$ & Group & \multicolumn{1}{c|}{ Mean } & \multicolumn{1}{c|}{$\begin{array}{c}\text { Std. } \\
\text { Error }\end{array}$} & \multicolumn{2}{c|}{ 95\% Confidence Interval } \\
\hline & & $\begin{array}{c}\text { Lower } \\
\text { Bound }\end{array}$ & $\begin{array}{c}\text { Upper } \\
\text { Bound }\end{array}$ & $\begin{array}{c}\text { Lower } \\
\text { Bound }\end{array}$ & $\begin{array}{c}\text { Upper } \\
\text { Bound }\end{array}$ \\
\hline MEAN POWER & 1 & 3.123 & .173 & 2.784 & 3.462 \\
\hline & 2 & 2.464 & .030 & 2.406 & 2.522 \\
\hline $\begin{array}{l}\text { MEAN } \\
\text { INFLUENCE }\end{array}$ & 1 & 3.435 & .145 & 3.150 & 3.719 \\
\hline & 2 & 3.297 & .025 & 3.249 & 3.346 \\
\hline $\begin{array}{l}\text { MEAN } \\
\text { RESISTANCE }\end{array}$ & 1 & 2.022 & .142 & 1.743 & 2.301 \\
\hline & 2 & 1.855 & .024 & 1.807 & 1.903 \\
\hline
\end{tabular}

Figure 6. Findings for Hypothesis 3 - Estimated Marginal Means Results

\section{Conclusions}

Based on the research findings of this study, the following conclusions are postulated:

1. The results between the "Conventional" stakeholder analysis and the "Multi-rater" stakeholder analysis methodology were inconclusive. However, the results reflect a limited research parameter for measurement: "relationship or no relationship." Given that this research measured three variables and the restrictive construct of the hypothesis measurement, the results most certainly assured an inconclusive finding. A more accurate predictor of relationship between the methodologies would have been an acceptable "mean range" between the variables for each methodology.

2. These results however must be viewed in the context of the primary research focus, which was to find an alternative methodological approach to measuring stakeholder influence. The 
results obtained in this research indicate that the "Multi-rater" methodology is both effective and comprehensive in identifying stakeholder interests.

\section{References}

Ackoff, R. (1974). Redesigning the future. New York: John Wiley \& Sons.

Aldrich, H., \& Whetten, D. (1981). Organization-sets, action-sets, and networks: Making the most of simplicity. In P. Nystrom \& W. Starbuck (Eds.), Handbook of organizational design. New York: Oxford University Press.

Altbach, P. G. (2002a). Perspectives on international higher education. Change, 34(3), 29-31.

Ansoff, H. I. (1965). Corporate strategy. New York: McGraw-Hill.

Ansoff, H. I., \& McDonnell, E. (1990). Implanting strategic management. New York: Prentice Hall.

Ball, S. J. (1987). The micro-politics of the school. London: Methuen.

Barzelay, M. (2001). The new public management: Improving research and policy dialogue. Berkeley, CA: University of California Press and Russell Sage Foundation.

Boschken, H. (1994). Organizational performance and multiple constituencies. Public Administration Review, 54(3), 308-312.

Bracken, D. W., Timmreck, C. W., \& Church, A. H. (2001). The handbook of Multisource feedback: The comprehensive resource for designing and implementing MSF processes. San Francisco: Jossey-Bass.

Bryson, J. M. (1995). Strategic planning for public and nonprofit organizations. San Francisco: Jossey-Bass.

Bryson, J. M. (2004). What to do when stakeholders matter. Public Management Review, 6(1), 21-53.

Bryson, J. M, Bromiley, P., \& Jung, Y. S (1990). Influences on the context and process on project planning success. Journal of Planning Education and Research, 9(3), 183-185.

Bryson, J. M, \& Bromiley, P. (1993). Critical factors affecting the planning and implementation of major projects. Strategic Management Journal, 14, 319-337.

Burby, R. (2003). Making plans that matter: Citizen Involvement and government action. Journal of the American Planning Association, 69(1), 33-50.

Campbell, J. P., McCloy, R. A., Oppler, S. H., \& Sager, C. E. (1993). A theory of performance. N. Schmitt \& W. C. Borman (Eds.), Personnel selection in organizations. San Francisco: Jossey-Bass.

DiMaggio, P. J., \& Powell, W.W. (1983). The iron cage revisited: Institutional isomorphism and collective rationality in organizational fields. American Sociological Review, 48(2), 147-160.

DeWit, H. (2002). Internationalization of higher education in the United States of America and Europe: A historical, comparative, and conceptual analysis. Westport: CT: Greenwood Press.

Dodd, E. M. (1932). For whom are corporate managers trustees? Harvard Law Review, 45(7), 1145-1163. 
Eden, C., \& Ackermann, F. (1998). Making strategy: The journey of strategic management. Thousand Oaks, CA: Sage.

Eden, C., \& Ackermann, F. (2002). Making strategy. London: Sage.

Evans, W. (1966). The organizational set: Toward a theory of inter-organizational design.

In J. Thompson (Ed.), Approaches to organizational design. Pittsburgh: University of Pittsburgh Press.

Feldman, M., \& Khademian, A. (2002). To manage is to govern. Public Administration Review, 62(5), 541-554.

Flexner, A. (1968). British Journal of Educational Studies, 17-18.

Freeman, R. E. (1984). Strategic management: A stakeholder approach. Boston: Pitman.

Frooman, J. (1999). Stakeholder influence strategy. Academy of Management Review, 24(2), 191-205.

Heclo, H. (1978). Issue networks and the executive establishment. In A. King (Ed.) The new political system. Washington, D.C.: American Enterprise Institute for Public Policy Research.

Jawahar, I. M., \& McLaughlin, G. L. (2001). Toward a descriptive stakeholder theory: An organizational life cycle approach. Academy of Management Review, 26, 397-414.

Johnson, G. \& Scholes, K. (2002). Exploring corporate strategy (6th ed.). Harlow, England: Pearson Education.

Kells, H. R. (1992). Self-regulation in higher education: A multi-national perspective on collaborative systems of quality assurance and control. London: Jessica Kingsley.

Kettl, D. (2002). The transformation of governance: Public administration for twenty-first century America. Baltimore, MD: Johns Hopkins University Press.

Latham, G. P., \& Wexley, K. N. (1994). Increasing productivity through performance appraisal (2nd ed.). Reading, MA: Addison-Wesley.

Lepsinger, R., \& Lucia, A. D. (1997). The art and science of 360-degree feedback. San Francisco: Jossey-Bass.

Levin, J. S. (2001). Globalizing the community college: Strategies for change in the twenty-first century. New York: Palgrave.

Light, P. (1997). The tides of reform: Making government work 1945-1995. New Haven, CT: Yale University Press.

London, M., \& Smither, J. W. (1995). Can multi-source feedback change perceptions of goal accomplishment, self-evaluations, and performance-related outcomes? Theory-based applications and directions for research. Personal Psychology, 48, 803-839.

Margerum, R. (2002). Collaborative planning: Building consensus and a distinct model of practice. Journal of Planning Education and Research, 21, 237-253.

Mitchell, R. K., Agle, B. R., \& Wood, D. J. (1997). Toward a theory of stakeholder identification and salience: Defining the principle of who and what really counts. Academy of Management Review, 22(4), 853-886.

Nadler, D. A. (1977). Feedback and organization development: Using data based methods. Reading, MA: Addison-Wesley. 


\section{Macrothink

Nutt, P. (2002). Why decisions fail: Avoiding the blunders and traps that lead to debacles. San Francisco: Berrett-Koehler Publishers.

Nutt, P., \& Backoff, R. (1992). Strategic management of public and third sector organizations: A handbook for leaders. San Francisco: Jossey-Bass.

Osborne, D., \& Plastrik, P. (1997). Banishing bureaucracy: The five strategies for reinventing government. Reading, MA: Addison-Wesley.

Peters, B. G. (1996). The future of governing: Four emerging models. Lawrence, KS: University of Kansas Press.

Powell, W. (1990). Neither marker nor hierarchy: network forms of organization. In B. Staw \& L. Cummings (Eds.) Research in organizational behavior. Greenwich, CT: JAI Press.

Preston, L. E., \& Sapienza, H. J. (1990). Stakeholder management and corporate performance. Journal of Behavioral Economics, 19(4), 361-375.

Radin, B. (2002). The accountable juggler. Washington, D.C.: Congressional Quarterly Press. Rainey, H. G. (1997). Understanding and managing public organizations (2nd ed.). San Francisco: Jossey-Bass.

Rainey, H. G. (2003). Understanding and managing public organizations (3rd ed.). San Francisco: Jossey-Bass.

Rainey, H. G., \& Steinbauer, P. (1999). Galloping elephants: Developing elements of a theory of effective government organizations. Journal of Public Administration Research and Theory, 9(1), 1-32.

Sims, R. (1999). Interactivity on stage: Strategies for learner-designer communication. Australian Journal of Educational Technology, 15(3), 257-272.

Tuchman, B. (1984). The march of folly: From Troy to Vietnam. New York: Knopf.

Van Schendelen, R. (2002). Machiavelli in Brussels: the art of EU lobbying. Amsterdam University Press.

Veblen, T. (1954). The higher learning in America: A memorandum of conduct of universities by businessmen. Stanford, CA: Academic Reprint.

Wolfe, M. (1998). Transitioning to a competency for pay system. Conference Proceedings of Linkage Incorporated, USA, 5, 203-279. 